\title{
THREE YEARS FOLLOW-UP OF SINGLE-STAGE CORRECTION WITH MODIFIED CHULA TECHNIQUE FOR FRONTOETHMOIDAL ENCEPHALOMENINGOCELE: THE ADVANTAGE OF THE TEAMWORK APPROACH (A CASE REPORT)
}

\author{
Loelita Marcelia Lumintang ${ }^{1 *}$, I Wayan Niryana ${ }^{2}$, Hendra Sanjaya $^{1}$, \& Agus Roy Hamid ${ }^{1}$ \\ 1. Division of Plastic Reconstructive and Aesthetic Surgery, Department of Surgery, Faculty of Medicine, Udayana \\ University/Sanglah General Hospital Bali, Denpasar, Bali, Indonesia \\ 2. Division of Neurosurgery, Department of Surgery, Faculty of Medicine, Udayana University/Sanglah General Hospital Bali,
} Denpasar, Bali, Indonesia

\begin{abstract}
Backgrounds: The main objective of Frontoethmoidal encephalomeningocele (FE) treatment are neural morbidities defect correction and aesthetically pleasing looks. Staged procedures are used to be performed in Indonesia. This article aimed to reveal the result of FE correction through the single-stage modified Chula technique (ST-MCT) procedure in collaboration with the neurosurgery team.

Case Reports: A rare case of 5 years old girl diagnosed with FE was reported in this study. The FE was slowly increased in size, causing apparent facial deformity and the appearance of telecanthus. An ST-MCT procedure in collaboration with the neurosurgery team was conducted to correct the defects. The IOD values, IPD values, postoperative complications, and anesthetic improvements were evaluated in this study.

Result: The patient was well after the surgery, with no complications and short length of stay. There were noted improvement of ICD, IOD and IPD postoperative follow up. At three years after the surgery ICD $=29 \mathrm{~mm}$; IOD= $26 \mathrm{~mm} ; \mathrm{IPD}=52 \mathrm{~mm}$ (normal range).

Summary: ST-MCT procedure conducted in collaboration with neurosurgery team had shown excellent correction of ICD, IOD, and IPD values, no complication, shorter length of stay, and minimal scars. It considers as the most proper technique to reach a good result of correction and aesthetically pleasing looks in FE cases.

Keywords: Frontoethmoidal Encephalomeningoceles; Frontoethmoidal meningoencephalocele; Surgical correction; Chula Technique
\end{abstract}

\section{ABSTRAK}

Latar Belakang: Tujuan utama pengobatan Frontoethmoidal encephalomingocele (FE) adalah koreksi cacat morbiditas saraf dan penampilan yang estetis. Tahapan-prosedur digunakan untuk dilakukan di Indonesia. Artikel ini bertujuan untuk mengungkap hasil koreksi FE melalui prosedur single stage modified Chula technique (STMCT) bekerja sama dengan tim bedah saraf.

Laporan Kasus: Kasus yang jarang terjadi pada anak perempuan berusia 5 tahun yang didiagnosis dengan FE dilaporkan dalam penelitian ini. FE perlahan-lahan meningkat dalam ukuran, menyebabkan deformitas wajah yang jelas dan munculnya telecanthus. Prosedur ST-MCT bekerja sama dengan tim bedah saraf dilakukan untuk memperbaiki cacat. Nilai IOD, nilai IPD, komplikasi pasca operasi, dan perbaikan anestesi dievaluasi dalam penelitian ini.

Hasil: Pasien baik-baik saja setelah operasi, tanpa komplikasi dan masa rawat yang singkat. Ada peningkatan ICD, IOD dan IPD tindak lanjut pasca operasi yang dicatat. Pada tiga tahun setelah operasi ICD $=29 \mathrm{~mm}$; IOD $=26 \mathrm{~mm}$; IPD= $52 \mathrm{~mm}$ (kisaran normal).

Ringkasan: Prosedur ST-MCT yang dilakukan bekerja sama dengan tim bedah saraf telah menunjukkan koreksi yang sangat baik dari nilai ICD, IOD dan IPD, tidak ada komplikasi, lama rawat yang lebih pendek, dan bekas luka yang minimal. Ini dianggap sebagai teknik yang paling tepat untuk mencapai hasil koreksi yang baik dan penampilan yang estetis dalam kasus FE.

Kata Kunci: Encephalomingoceles frontoethmoidal; meningoensefalokel frontoethmoidal; Koreksi bedah; Teknik Chula

\section{Conflicts of Interest Statement:}

The author(s) listed in this manuscript declare the absence of any conflict of interest on the subject matter or materials discussed. 


\section{INTRODUCTION}

Encephalocele is a protrusion of cranial contents beyond the normal confines of the skull. They may contain meninges (meningocele), brain matter, and meningoencephalocele, or they may communicate with the ventricles (meningoencephalocystocele). ${ }^{1}$ Anterior encephalocele is a neural tube defect and is considered an extremely rare condition. ${ }^{2}$ Frontoethmoidal encephalomeningocele (FE) is a rare case in western countries. But it relatively frequents in Southeast Asia. ${ }^{3}$

Patient with FE is vulnerable of central nervous system infection, craniofacial disfigurement, binocular vision, impairment of nasal function, visual acuity, bilateral blindness, strabismus, and lacrimal obstruction. Further complications could be prevented by administering definitive correction at the early stage of age (infancy).$^{4}$ No significant differences note on the skin over the mass. The skin usually appears normal in appearance, thin, shiny, thick, or wrinkled. Hyperpigmentation and hypertrichosis also could be seen in some cases.5,6 Commonly, the walls of the medial orbit in FE have been displaced. Therefore, their orbital configuration may be found abnormal due to the asymmetric encephaloceles. ${ }^{5}$

Two and three-dimensional CT-Scan results presented essential clinical information about the condition's bony and soft tissue pathology. The objective of this correction procedure was urgent closure, nonfunctional tissue removal, and reconstruction of the total craniofacial. ${ }^{9}$ A collaboration between experts in the neurosurgical and plastic surgical field proposes an ideal correction procedure in this case.

This study elaborated a successful, innovative, and simple surgical technique that produced minimal scar for FE correction in a child who had undergone a modified one-stage Chula repair.

\section{CASE REPORT}

A 5-years-old girl with a history of congenital midline upper nose swelling was admitted to a surgical clinic. The swelling was located on the right side of her nose bridge. The FE was slowly increased in size, causing apparent facial deformities and the appearance of telecanthus. The ICD, IOD, and IPD was 38,35 and $62 \mathrm{~mm}$, respectively. It did not grow in size during usual activity or crying and was confirmed to be not associated with rhinorrhea, visual impairment, or abnormality in eye movements. She was healthy and tolerating feeding. No signs or symptoms related to the increase in intracranial pressure were noted during the assessment. She appeared active with no growth and development issues found during the anamnesis.

No dysmorphic features were found from the general examination. The swelling located on the right side of the nose bridge measured about $3 \times 2 \mathrm{~cm}$, soft in consistency, non-tender, fixed to inside deeper tissues, and non-pulsatile with palpable bony defect at the base of the nose. The cranial nerves were intact, with no systemic abnormalities and signs of lacrimal obstructions. Initial CT scans (Figure 1) revealed a mass located between the orbits. The mass is identified as isodense as the brain tissues and connected to the brain tissues with a bony defect at that region. According to these findings, the patient was planned for a first-stage operation. This was a reduction procedure in the herniated brain tissue at the frontoethmoidal area with autograft bone aimed to close the bony defect.
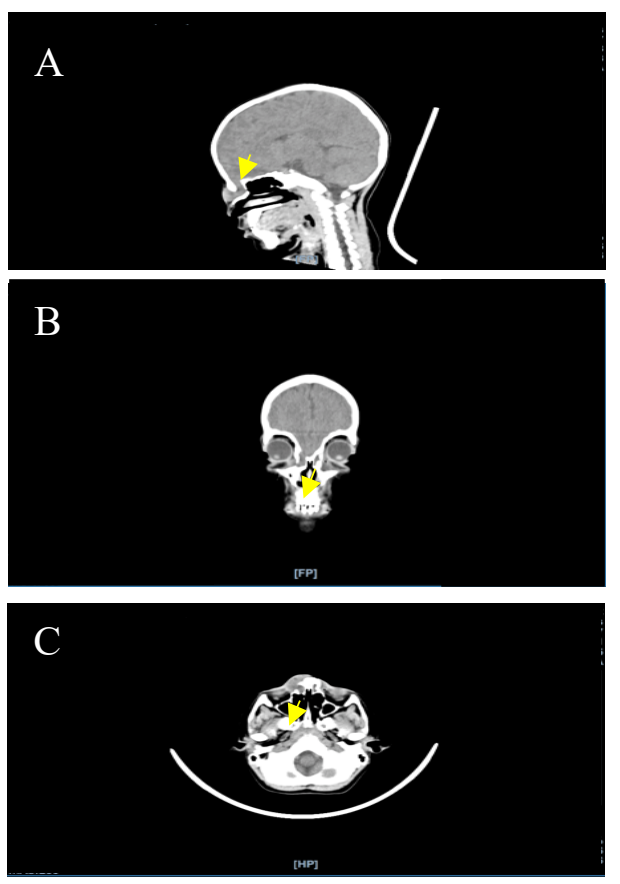

Figure 1. Head CT Scan Images, (Yellow arrows) A. Sagittal image of intracranial communication with soft tissue mass that occupied the right side of the nasal bridge, B. Defect on the cribriform plate, and C. Soft tissue mass located on the right side of the nasal bridge. 
The patient was lying horizontally (supine) with the head elevated to 30 degrees above the heart during the surgery. After the shaving, cleaning, and draping procedure of the surgery area, local infiltration of pehacain $2 \%$ was conducted in the subcutaneous tissue. A bicoronal skin incision (Figure 2) was made from the left temporal, anterior to the tragus, to the same point on the opposite side. Bleeding on the skin edges is secured and prevented by using the rinnies' clips. Scalp dissection was conducted to the lower limit of the defect or abnormality. The Galea layer was incised by monopolar diathermy and periosteum. The periosteum had been alienated from the layer of bony by a periosteal elevator before this procedure. Smith craniotomes and dura spatulas were used to do the procedure of craniotomy on the right side of the nose's bridge. The encephalocele was approached through the extradural route.

After the nasal bone defect had identified, it was being opened. A surgical reduction of the herniated brain was then performed. After that, the dura layer was resutured, and the galea tissue was lined. Then, 1-2 $\mathrm{ml}$ of fibrinogen products was administered onto this area.

The reconstruction of the bony defect was conducted by applying a graft of autogenous bone from the fragment part of the Burr hole. The bilateral orbital frames were approximated closely by fibrous tissue excision and bones at the nasal region. Then the canthopexy procedure is performed to correct the medial canthal ligament bilateral to the nasal bone. Cranial graft applied to support the dorsal nasal in correcting the deformity of the nasal (Figure 3). The neurosurgery team conducted the subsequent
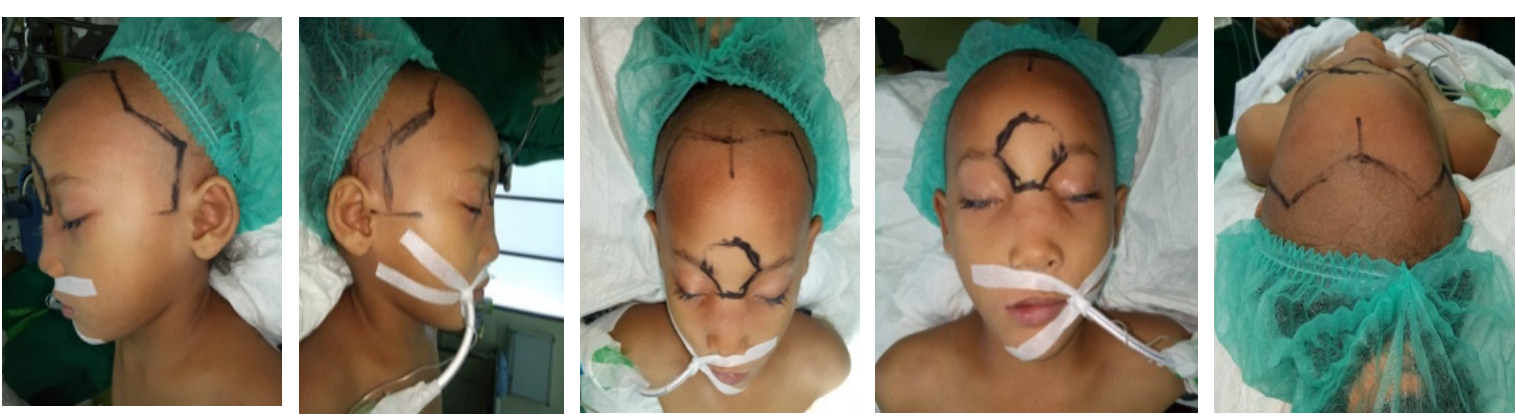

procedures. They continued the piece of frontal craniotomy. After that, the bicoronal plating closure was undertaken to end the procedure (Figure 4).

\section{RESULTS}

Figure 5 shows the value of ICD and IOD after the surgery. Figure 5a., 5b., 5c., 5d., 5e., 5f., $5 \mathrm{~g}$., and $5 \mathrm{~h}$. reveals the value of ICD and IOD one day $(\mathrm{ICD}=33 \mathrm{~mm} ; \mathrm{IOD}=29 \mathrm{~mm} ; \mathrm{IPD}=53 \mathrm{~mm})$, one month $(\mathrm{ICD}=33 \mathrm{~mm} ; \mathrm{IOD}=29 ; \mathrm{IPD}=54 \mathrm{~mm})$, two months $(\mathrm{ICD}=31 \mathrm{~mm}$; IOD $=26 ; \mathrm{IPD}=50$ $\mathrm{mm})$, three months $(\mathrm{ICD}=28 \mathrm{~mm} ; \mathrm{IOD}=25 \mathrm{IPD}=$ $48 \mathrm{~mm})$, four months $(\mathrm{ICD}=28 \mathrm{~mm}$; $\mathrm{IOD}=24$; $\mathrm{IPD}=47 \mathrm{~mm})$, five months $(\mathrm{ICD}=27 \mathrm{~mm}$; IOD $=$ $23 \mathrm{~mm}$; IPD $=47 \mathrm{~mm})$, six months $(\mathrm{ICD}=28 \mathrm{~mm}$ $\mathrm{IOD}=23 ; \mathrm{IPD}=48 \mathrm{~mm})$, and three years after the surgery $(I C D=29 \mathrm{~mm} ; \mathrm{IOD}=26 \mathrm{~mm} ; \mathrm{IPD}=52 \mathrm{~mm})$, respectively.

She was well after the surgery (Figure 5a.). The broad-spectrum antibiotics were prescribed and administered to the patient. On the first day after the surgery, a colorless fluid dripped out through her nasal, and it was tested positive for CSF. The patient was conservatively managed after the surgery. After the second day of surgery, there was no fluid dripped from the nasal. She made a good recovery. The ICD, IOD, and IPD values were identified in the normal range.

Figure 2. Preoperative Incision Design 
a.

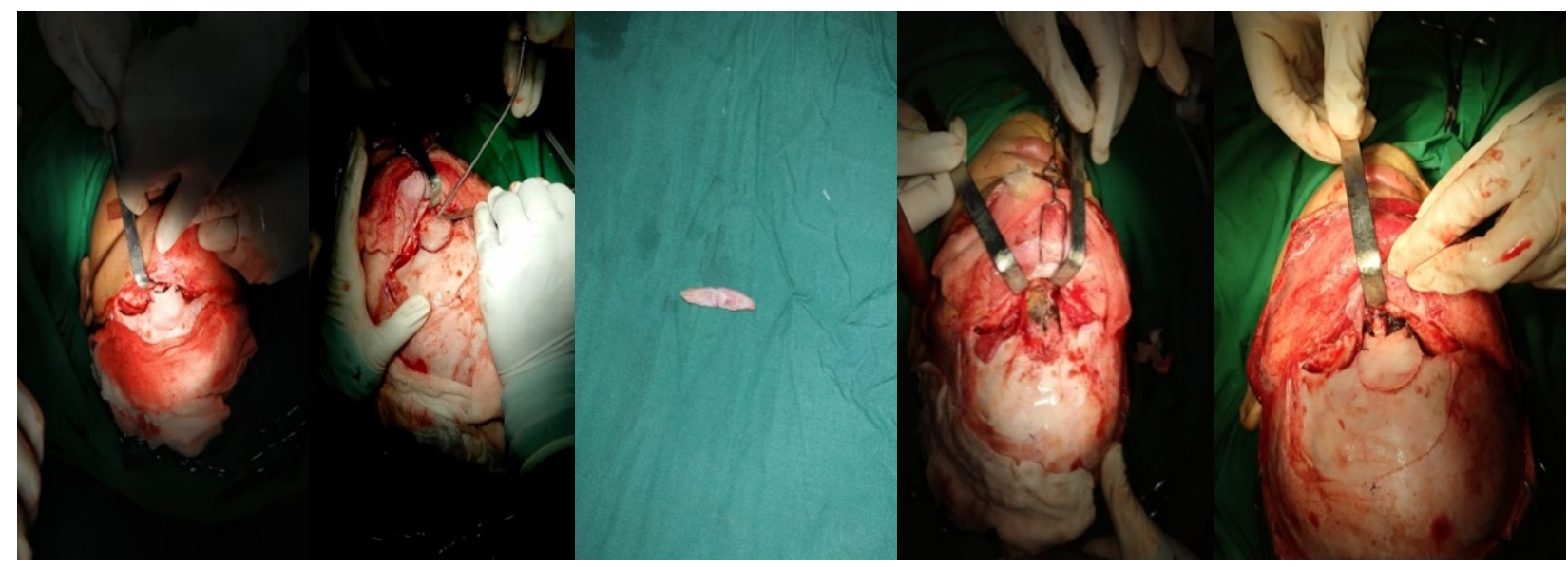

b.
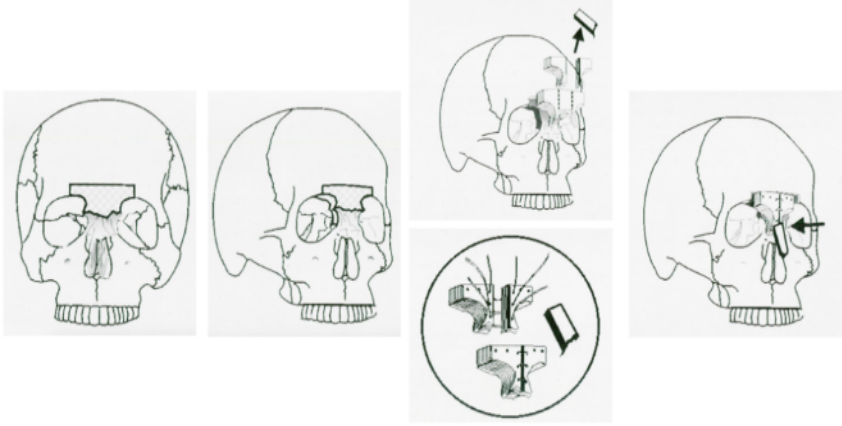

Figure 3. a. Durate operation osteotomy necrotomy, canthopexy, and bone graft for dorsum nasal, b. Illustration ${ }^{23}$
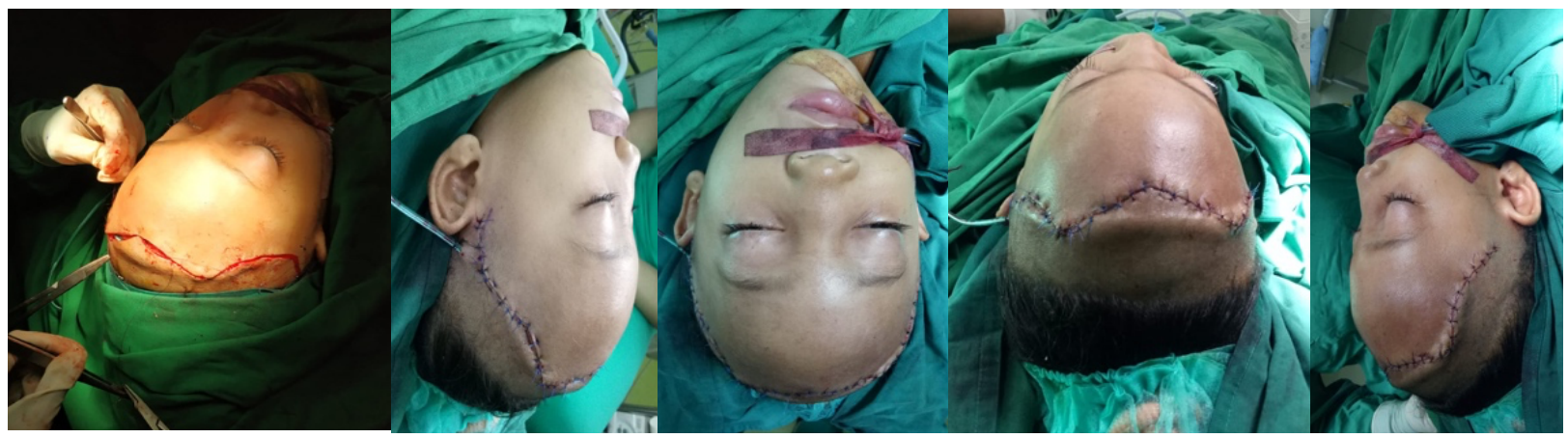

Figure 4. Postoperative closure 


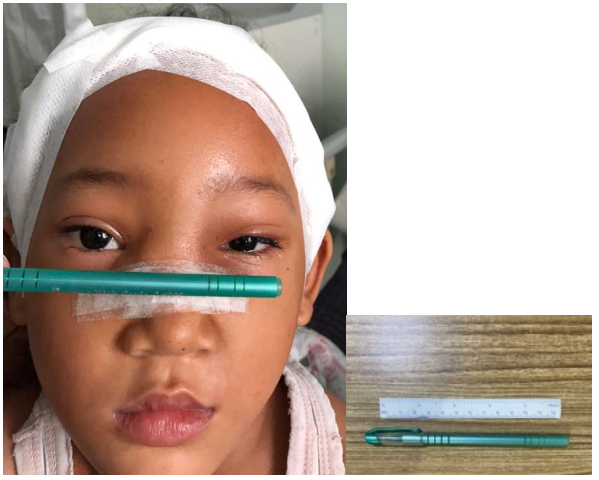

a.

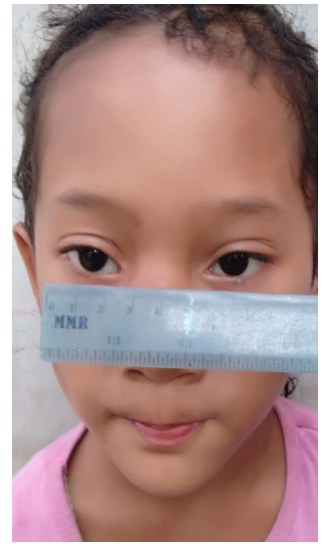

e.

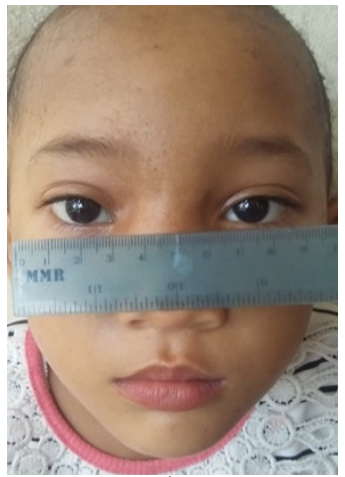

b.

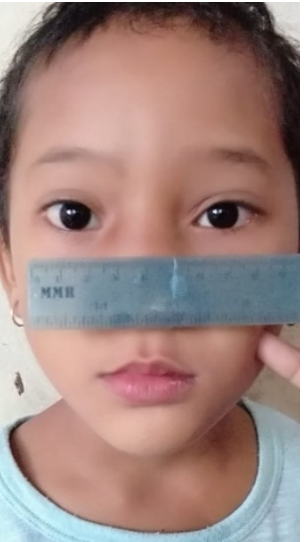

f.

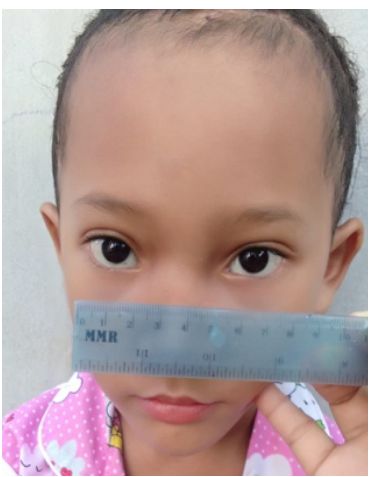

C.

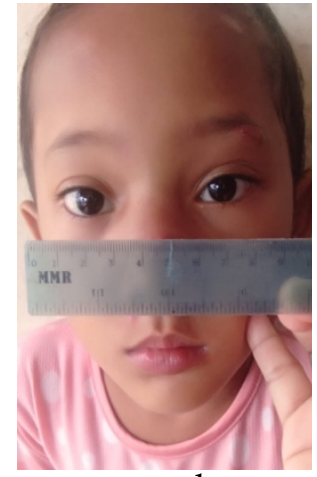

d.

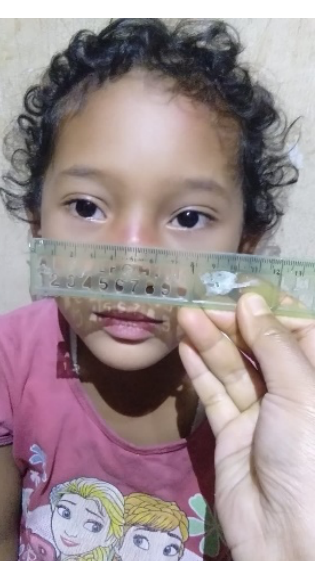

g.

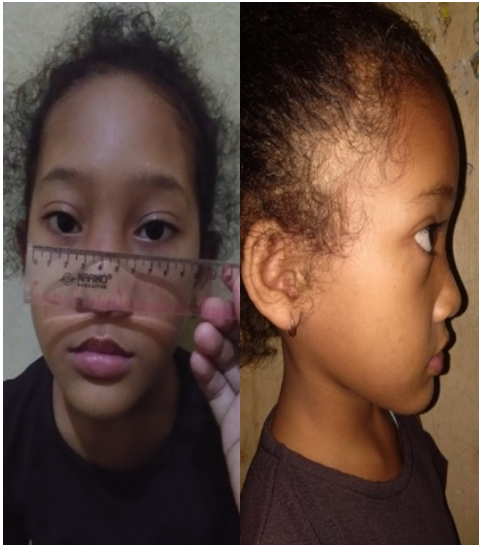

h.

Figure 5. a. One day after surgery, b-g. Six months after surgery and h. Three years after surgery

\section{DISCUSSION}

Anterior encephalocele is an extremely rare congenital abnormality case encountered by one of 5,000 live births in Southeast Asian countries. Anterior encephalocele was an anterior neuropore of the neural tube defect closure that caused herniation of the intracranial components through the cranial and facial bone. ${ }^{10}$ These lesions were frequently found in the lowsocioeconomic-class children population. But no scientific evidence had clearly explained the causes. ${ }^{11}$ Its pathogenesis has been postulated to be a defect in the neuropore closure during embryogenesis that finally resulting in herniation of the intracranial contents. A failure of surface and neuroectoderm separation at the neural fold in the midline during the fourth week of embryonic life causes encephalocele development.5,12 The potential causes of this defect could be genetic component-occurring in families with spina bifida and anencephaly, teratogens $\mathrm{x}$-ray irradiations, trifan blue, vitamina, arsenic, or others. Encephaloceles also can be congenital or acquired secondary to a tumor, hydrocephalus, or other causes.13 Neural tube defects, such as spina bifida, also can lead to frontoethmoidal meningoencephaloceles. This evidence suggested a role of folate deficiency, although there was not much documentation on the correlation between maternal folate levels and its incidence found..$^{14}$

Many other theories of frontoethmoidal meningoencephaloceles had postulated the development process of an anterior encephalocele. 15 The first theory stated that the primary osseous defect leads to the failure of the ethmoidal plate to close around the olfactory nerve. At the later stage, herniation of the brain could have happened. The second theory explained that increased ventricular pressure in the embryo could push the developing brain through the incompletely developed osseous structures. 
Based on the area of the skull defect, the extracranial pathway of the herniation and the facial presentation are classified as occipital, encephalocele of the cranial vault, frontoethmoidal, and basal. Frontoethmoidal encephalocele was categorized by referring to a system introduced by Suwanwela and Suwanwela and based on the work by Mesterton. ${ }^{16}$ It was classified as nasofrontal, nasoethmoidal, and naso-orbital. At the same time, the basal category consisted of transethmoidal, transsphenoidal, sphenoethmoidal, and spheno-orbital lesion. Nasoethmoidal encephalocele was the most common subtype.5,6,12

The nasoethmoidal type is situated between the nasal bone and nasal cartilage. The nasal bone was deformed and often broadened with crimped margins. The frontonasal angle was obliterated, producing the appearance of an overhanging ledge. If the facial defect is confined to the nasal pyramid, small and oval, no involvement of the medial walls would be found. If it was more extensive, the facial defect could be extended toward the lateral direction. Anterior margins of the medial orbital walls were then eroded and crescent-shaped. Defects occurred on the medial orbital walls in the naso-orbital type. It was located in the frontal process of the maxilla and the lacrimal bones. ${ }^{15}$

Frontoethmoidal encephalocele was associated with the craniofacial deformity. Interorbital hypertelorism was an example of this deformity. Orbital hypertelorism or telorbitism rarely happened because a dilated lateral orbital wall did not follow the widened wall of the medial orbital. Consequently, interorbital hypertelorism presented a decent presentation of a skeletal deformity. ${ }^{12}$

The treatment of all types of encephaloceles is surgical excision. Based on the location of the defect, various approaches administered are trans-nasal, lateral rhinotomy, and coronal flap approach. ${ }^{10}$ The goals of FE correction are (1) urgent closure of open skin and intracranial bone defects (infection prevention and possible brain tissue desiccation), (2) removal of nonfunctional extracranial cerebral tissue with water-tight closure of the dura, and (3) total craniofacial reconstruction with particular emphasis on exact skeletal reconstruction, especially in avoiding the "long-nose deformity"9. The procedure of surgical repair of the lesion (anterior encephalocele) is usually conducted for aesthetic purposes. Computed tomography (CT) scans with appropriate bony and soft tissue brain windows and three-dimensional reconstruction presented sufficient information. Thus, scans are an integral part of surgical planning 2 .

Several surgical techniques had conducted in frontoethmoidal encephalomeningocele removal procedures. Two-stage correction by preliminary intracranial disconnection and subsequent extracranial correction of the facial deformity ${ }^{17}$ used to be performed in Indonesia. The typical Tessier approach consisted of trepanation and detachment, realignment, and refixation as the hypertelorism was being corrected, craniofacial and neurosurgical expertise roles required in the procedure. These interventions commonly produced massive blood loss and more extended postoperative care. ${ }^{18}$

The nasal-coronal approach was quite popular in treating most cases of FE. The nasalcoronal approach presents a vast area of exposure and a single stage of the procedure. A pure extracranial system was also introduced in treating FE. This approach offered feasibility in treating FE cases in countries encountered difficulties in performing craniotomy procedure. Unfortunately, the neck's exposure was limited in this procedure due to the size of the external bony defect. The vulnerability was quite adequate in dealing with small meningoceles, but not for larger meningoceles. ${ }^{19}$ The pure extracranial approach was vulnerable to a higher risk of side effects incidence on the donor-sites. It is usually associated with the closure of external defects or nasal reconstruction, for example, the unicortical calvarial bone graft. 20

Mahatumarat et al. have proposed another nasal-coronal approach procedure, the Chula technique $^{16}$, which substituted a T-shaped osteotomy of the frontonasal-orbital bone for the formal and extensive frontal craniotomy. Chula technique offered limited frontal osteotomy, lower risk of spinal fluid leakage $(2.8 \%)$, and lower incidence of meningitis. The resected middle portion of the T-shaped osteotomized bone could augment the nose and decrease the distance between the medial orbital walls. ${ }^{21}$ The site, size, the content of encephalocele, and associated congenital anomaly determined the prognosis of the survivor. The survival rate of anterior encephalocele was higher than posterior encephalocele, with $100 \%$ and $55 \%$, respectively. It happened due to the vital structure of the brain parenchyma might have herniated to the skull defect. $^{16}$ Adequate area of exposure in 
performing medial canthopexy presented by this approach. The area exposed is vital since medial canthal ligaments commonly had been displaced on their "superior, anterior, or posterior" side from the mass in FE cases. ${ }^{22}$

Therefore, a clear advantage of the Chula technique was the osteotomy design capable of closing the external defect and providing adequate bone graft for the reconstruction procedure. These procedures also cause fewer side effects on the donor-site cases. Collaboration with the neurosurgeons also delivered more benefits since proper dural closure was likely presented in the collaboration. Besides that, beneficial outcomes, the acceptable value of IOD and IPD, aesthetically pleasing scar, and the potential to be applied in various sizes and locations of FE cases are also provided using this procedure on a single-stage teamwork approach. ${ }^{23}$

In our case, we had modified the Chula technique, coronal approach, direct osteotomy on the defect area, and using the rest of the bone as a bone graft for the dorsum nasi. This method was relatively simple. It lowered the risk of complication, at the same time, corrected the encephalocele, and restored the aesthetic appearance (nasal augmentation with shorter surgery duration and technique). The result of the surgical correction was evaluated by IOD and IPD values. The interpupillary distance was defined as the distance between the medial of the pupil.24

There was an improvement of ICD and IOD values in the follow-ups (based on their normal value) ${ }^{24}$ after the surgery noted in this study. We also found no signs or symptoms of recurrences and complications after three years of surgery.

\section{SUMMARY}

Frontoethmoidal encephalocele considers as a rare medical condition. It causes cosmetic and functional issues for their survivor. Comprehensive surgical treatment on frontoethmoidal meningoencephaloceles cases should be done by pathologic tissue resection, mentoplasty procedures, osseous defect restoration, and facial deformities reconstruction (bone and soft tissue).

This case report revealed that the modified Chula technique was a proper procedure for reconstruction and aesthetic aspect on the encephalocele cases. It involved minimal surgical intervention and reconstruction; hence, it could minimize the scars, produce a shorter length of stay, and more rapid recovery. After three years of surgery, it could also achieve the main objective without any complications and recurrences.

Correspondence regarding this article should be
addressed to:
Loelita Marcelia Lumintang
Division of Plastic Reconstructive and Aesthetic Surgery,
Department of Surgery, Faculty of Medicine Udayana
University/Sanglah General Hospital Bali, Denpasar, Bali,
Indonesia, Denpasar City, 80234, Indonesia
Email: drloelitamlumintang@gmail.com

\section{ACKNOWLEDGEMENT}

We thank the patient and her guardians for their precious support, contribution, and participation in this study.

\section{REFERENCES}

1. Suwanwela C, Suwanwela N. A morphological classification of sincipital encephalomeningoceles. J Neurosurg. 1972;36:201-11.

2. Mahapatra AK, Agrawal D. Anterior encephaloceles: A series of 103 cases. Journal of Clinical Neuroscience. 2006;13:536-9.

3. Suwanwela, C., Sukabote, C., Suwanwela, N Frontoethmoidal encephalomeningocele. Surgery. 1971;69: 617.

4. David, D. J Cephaloceles: Classification, pathology, and management. A review. J. Craniofac Surg. 1993;4:192.

5. Tandon PN. Meningoencephalocoeles. Acta Neurol Scand. 1970;46:369-83.

6. Tebruegge $M$, Curtis N. Epidemiology, etiology, pathogenesis, and diagnosis of recurrent bacterial meningitis. Clin Microbiol Rev. 2008;21:519-37:SEp:

7. Salyer KE. Aesthetic craniofacial surgery. 1989. New York, 83-8.

8. Jackson IT, Tanner NSB, Hide TAH. Frontonasal encephalocele is "long nose hypertelorism". Ann Plast Surg. 1983; 11(60):490-500.

9. Holmes AD, Meara JG, Kolker AR, Rosenfeld JV, Klug GL. Frontoethmoidal Encephaloceles: reconstruction and refinements. J Craniofac Surg. 2001;12:6-18. 
10. David DJ. Cephaloceles: Classification, pathology, and management - A review. J Craniofac Surg. 1992;4:192-202. [i] [']

11. Christopher GM, Richards. Frontoethmoidal meningoencephalocele: a common and severe congenital abnormality in South East Asia Archives of Disease in Childhood. 1992;67: 717-9.

12. Von Meyer E. About a basal herniation in the area of lamina cribrosa. Virchows Arch Pathol Anat Physiol Klin Med. 1890; 120:309-20.

13. Kak VK, Gulati DR.The familial occurrence of frontoethmoidal encephaloceles. Neurol India 1973;21:41-3.

14. Holmes AD, Meara JG, Kolker AR, Rosenfeld JV, Klug GL. Frontoethmoidal encephaloceles: Reconstruction and refinements. J Craniofac Surg. 2001;12:6-18.

15. Bhagwati S, Mahapatra A. Encephaloceles and anomalies of the scalp. Pediatric Neurosurgery. Churchill Livingstone; 1999. pp 101-120:

16. Mesterton CB. Ommedfödt hjarnbråck. 1885. Dissertation, Upsala University

17. Lello GE, Sparrow OC, Gopal R. The surgical correction of fronto-ethmoidal meningoencephaloceles. J Craniomaxillofac Surg. 1989;17:293-8.

18. Tessier, P. Orbital hypertelorism I: Successive surgical attempts. Material and methods. Causes and mechanisms. Scand. J. Plast. Reconstr. Surg. 1972;6:135.

19. Holm C, Myatt T, Anderl H, Mayr M, GogelerSchroder S, Schoneich W. Extracranial
Correction of Frontoethmoidal Meningoencephaloceles: Feasibility and Outcome in 52 Consecutive Cases. Plast. Reconstr. 2008;121: 386e.

20. Kline, R., and Wolfe, A. Complications associated with the harvesting of cranial bone grafts. Plast. Surg. 1995; 95: 5.

21. Mahatumarat C, Rojvachiranonda N, Taecholarn C. Frontoethmoidal encephalomeningocele: Surgical correction by the Chula technique. Plast Reconstr Surg. 2003; 111:556-65.

22. Ur Rahman N. Nasal Encephalocele. Journal of the Neurological Science. 42:73-85.

23. Kusumastuti N, Handayani S, Hatibie M, Diah E, Bangun K. Frontoethmoidal Encephalomeningocele Revisited: The Convenience of Teamwork Approach, A Case-Series. Jurnal Plastik Rekonstruksi. 2012;1(5):493-8.

24. Davidson EH, Losee JE. Pediatric facial features. Plastic surgery: craniofacial, head and neck surgery and pediatric plastic surgery: 4th ed: Saunders Elsevier; 2018. p. 678-695.

25. Etezad-Razavi M, Jalalifar, S. Correlation between interpupillary and inner-outer intercanthal distances in individuals younger than 20. J Ophthalmic Vis Res. 2008; 3(1):16-22.

26. Agrawal J, Yogesh AS, Shukla CK, Banerjee C, Chandrakar AK. Orbitofacial anthropometric assessment of inter-canthal and outer canthal distance measurement in Chhattisgarh region. Biomed Res. 2012;4(3):365-9. 